\title{
Mobile Communication and Civic Life: Linking Patterns of Use to Civic and Political Engagement
}

\author{
Scott W. Campbell \& Nojin Kwak \\ Department of Communication Studies, University of Michigan, Ann Arbor, MI 48104, USA
}

\begin{abstract}
This study employed the uses and gratifications approach to investigate how patterns of mobile phone use are linked to civic and political involvement. Findings reveal that use of the technology for information exchange and recreation are positive predictors of participation in civic life, however associations are moderated by mobile communication competence. Notably, individuals who report higher levels of comfort with mobile telephony and use it for information exchange tend to be more civically and politically engaged than those who report less comfort with the technology. These findings shed new light on the positive role of mobile communication in civil society, while highlighting competence as an emergent dimension of the so-called "second-level" digital divide, which has traditionally focused on computer skills.
\end{abstract}

doi:10.1111/j.1460-2466.2010.01496.x

The health of American democracy has become a topic of increasing concern in recent years. Much of this concern comes out of Putnam's (1995a, 2000) empirically based argument that Americans have become less politically active, less trusting of their government, and less involved in civic and community activities. Putnam attributes the steady decline of civic engagement in American society to the privatization of leisure time, noting that consumption of electronic media, especially television, contributes to this trend. There is some evidence supporting this hypothesis. For example, Norris (1996) and Shah, Kwak, and Holbert (2001) report that overall television viewing is negatively related to forms of political and civic involvement. However, these studies also reveal that certain forms of television viewing, such as watching news programs, reverse this trend with positive associations, demonstrating that the role of a given medium in civic life is dependent upon patterns in its use.

The ascent of new media, particularly the Internet, has given rise to a new wave of hopes and fears. Some warn that Internet use can displace face-to-face sociability

Corresponding author: Scott W. Campbell; e-mail: swcamp@umich.edu 
(e.g., Kraut et al., 1998; Nie \& Erbring, 2002), while others celebrate new ways of connecting with others (e.g., Hampton \& Wellman, 2001; Wellman, Boase, \& Chen, 2002). The emergence of mobile communication technology warrants another step with research and theory on the intersections between new media and civic involvement. Mobile subscriptions are well into the billions, making it among the fastest growing communication technology ever (Castells, Fernandez-Ardevol, Qiu, \& Sey, 2007). Yet, researchers are only beginning to understand the role of the technology in civic participation. This study offers a step forward by reporting on findings from a survey of U.S. adults that furthers our understanding of whether and how mobile communication is a resource for civic and political involvement. Rather than simply looking at how much one uses mobile communication technology, we examine the extent to which patterns of use play a role in civic life. The presumption here is that the role of mobile communication in these activities depend just as much on how one uses the medium as how much, if not more so.

Although research in this area is notably thin, there is a small foundation upon which to build. In a study of several European countries and Israel, Ling, Yttri, Andersen, and Diduca (2003) found text messaging to be significantly and positively associated with membership in community and political organizations, while voice calling was not. In a similar study of the United States, Campbell and Kwak (2010) found that for certain groups of mobile phone users, voice calling was significantly linked to civic and community engagement, while text messaging was not. It is noteworthy that these studies yielded disparate findings. It is also noteworthy that both focused on levels of use rather than purposes for use. In order to better understand how the technology serves as a tool for civic and political participation, this study takes an alternative approach by drawing from the uses and gratifications $(\mathrm{U} \& \mathrm{G})$ framework to explore how patterns of use are linked to participation in civic and political affairs.

$U \& G$ is a theoretical orientation developed to highlight how user needs and motivations shape media use and other outcomes, as opposed to the "effects" of simple exposure to media content (Blumler \& Katz, 1974). Rooted in traditional mass communication channels such as television, radio, and print media, some fundamental purposes for media use include fulfilling needs for information, social interaction, entertainment, and personal identity (McQuail, 1983). In recent decades, scholars have expanded the U\&G framework beyond traditional mass media to account for the use of interpersonal and hybrid channels, such as the landline telephone, Internet, and mobile phone.

Much of the research on the landline telephone suggests that individuals use this medium to meet social, instrumental, and entertainment needs (LaRose \& Mettler, 1990; O’Keefe \& Sulanowski, 1995; Williams, Dordick, \& Jesuale, 1985). In addition, researchers have found reassurance (particularly that close friends and loved ones are all right) to be a primary purpose for telephone use (Dimmick, Sikand, \& Patterson, 1994). With regard to Internet use, studies primarily point to needs for information, social interaction, and entertainment (Charney \& Greenberg, 2002; 
December, 1996; Eighmey \& McCord, 1998; Kaye, 1998; Papacharissi \& Rubin, 2000), although a number of other functions such as learning (Eighmey \& McCord, 1998; Perse \& Ferguson, 2000), commerce (Norris \& Jones, 1998), and financial management (Shah et al., 2001) have also been identified. As is typical with other media, fundamental purposes for using the mobile phone include both social and instrumental dimensions. Wei and Lo (2006) identify social utility, affection, and information-seeking as some of the key functions of the technology. In addition, researchers have found that purposes for mobile phone use include fashion/status, mobility, immediate accessibility, and recreation/entertainment (Leung \& Wei, 2000; Wei, 2008; Wei \& Lo, 2006).

Most of the research cited above explores how needs and motivations predict media usage patterns, often while accounting for user differences such as age, gender, and personality traits. Although emphasis has been placed on user motivations, media usage patterns and their consequences are also integral components of the U\&G framework (Katz, Blumler, \& Gurevitch, 1974). In fact, Finn (1997) argues the "most critical" components of this model are "(a) the social and psychological origins of audience needs, (b) the different patterns of media exposure that purportedly result, and (c) the differential engagement in other activities" (pp. 508-509). This study draws from these last two "critical" elements to investigate whether differential forms of use are linked to engagement in civic and political activities. Although this is not a full application of the U\&G framework, this approach has also been utilized in previous research grounded in the U\&G tradition (Shah et al., 2001). Predictor variables of interest include mobile phone use for (a) information exchange about news and public affairs, (b) sociability with family and peers, and (c) personal recreation. These categories were arrived at through factor analysis, and previous research and theory provide grounds to anticipate that each may play a distinctive role in whether and how mobile communication is linked to civic and political involvement.

With regard to the first, studies show that use of both traditional and new media for surveillance of public affairs plays a positive role in civil society by providing individuals with information to reflect and deliberate on civic and political matters (Shah, Cho, Eveland, \& Kwak, 2005). For example, Mcleod et al. (1996) and McLeod, Scheufele, and Moy (1999) found that reading newspapers and watching local news are positively associated with community engagement. Television use for news and public affairs programming has been linked to civic and political involvement in other studies as well (Norris, 1996; Shah, 1998; Shah et al., 2001). Investigations have also linked informational uses of the Internet to participation in civic and political activities (Shah et al., 2001, 2005). These studies demonstrate how media consumption for informational purposes plays a positive role in connecting individuals to the civic and political spheres of social life. We anticipate similar results for this use of mobile telephony, not only because it would be consistent with the previous research, but also because the medium offers a heightened level of flexibility for information exchange by allowing users to talk about issues with others, in addition to textual exchange and information retrieval. 
H1: Use of the mobile phone for information exchange will be a positive predictor of both civic engagement and political participation.

With regard to sociability, Coleman (1990) argues that civic and political engagement can be an unintended by-product of socializing with friends and family members. The idea here is that informal social connections foster trust in others and environments for political discussion and mobilization (Putnam, 1995a, 1995b). As Kwak, Shah, and Holbert (2004) explain, "the familiarity and equity that characterize informal associations likely encourage open interactions (Newton, 1997), thereby causing individuals to be receptive to information and opportunities that arise out of these forms of social connection" (p. 644). On the other hand, there is also reason to question whether mobile phone use for sociability plays a constructive role in civic and political engagement. Compared to other media, the mobile phone is a characteristically personal device, and some primarily use it for connecting with social network ties (Campbell \& Park, 2008; Ling, 2004, 2008). Although this form of bonding strengthens core networks, it raises concerns about "telecocoons" of like-minded individuals (Habuchi, 2005), which may lead to insularity and the degradation of open deliberation in the democratic process (Gergen, 2008). Competing lines of reasoning and a lack of empirical evidence do not provide sufficient grounds to state a directional hypothesis regarding the role of mobile-mediated sociability in pubic affairs participation, therefore we have formulated the following research question:

RQ1: In what way is mobile phone use for sociability with informal ties associated with civic engagement and political participation?

As noted, entertainment is also a prominent use of both old and new media. Most of the existing research suggests that recreational use of traditional media, particularly television, does not contribute to engagement in civic life (Besley, 2006; Shah et al., 2001; Sotirovic \& McLeod, 2001). However, studies of television viewing offer shaky grounds for making predictions about mobile-mediated recreation. Mobile telephony takes the notion of an active audience to new levels, considering much of the content is generated by the users themselves through their connections with others. From an active audience perspective, the Internet (also a highly interactive, hybrid medium) is better suited than traditional mass communication channels for generating a hypothesis about mobile-mediated recreation. Entertainment uses of the Internet are thought to have adverse civic consequences (Cho, Rojas, \& Shah, 2003), however there is limited empirical evidence supporting this claim. Most notably, Shah et al. (2001) found consistently negative associations between recreational use of the Internet and social capital indicators, however their findings are statistically significant only in intragenerational analyses. Given these findings, and considering literature in this area is rather thin, we only cautiously predict that recreational use of mobile technology will be negatively associated with civic and political involvement. 
H2: Use of the mobile phone for recreation will be a negative predictor of both civic engagement and political participation.

In addition to patterns of use, the extent to which one is comfortable with mobile telephony may also have an impact on its role as a resource for engaging in civic society. Indeed, competence with new media, especially the Internet, has become a growing concern among scholars investigating the digital divide (Hargittai, 2002; van Dijk, 1999; van Dijk \& Hacker, 2003). Presumably, this is an important consideration for mobile communication as well. To illustrate, those more comfortable with accessing the Web through their mobile handsets would seem better able to obtain and distribute information about civic and political matters. Mobile communication competence may have an impact on other uses as well, such as sociability. In the context of computer-mediated communication (CMC), research indicates that those with higher levels of comfort tend to benefit more from relational uses of the technology (Campbell \& Neer, 2001; Hacker \& Steiner, 2001; Tewksbury \& Althaus, 2000). Furthermore, CMC efficacy can mitigate certain negative outcomes, such as feelings of loneliness and depression that have been associated with its use (LaRose, Eastin, \& Gregg, 2001). Accordingly, we anticipate that comfort with mobile telephony may significantly interact with patterns of use.

RQ3: To what extent does competence with using mobile telephony interact with mobile phone use for (a) information exchange, (b) sociability, and (c) recreation to predict civic and political participation?

\section{Method}

\section{Sample}

The data for this study came from a national mail survey that was conducted in the United States immediately following the 2006 midterm Congressional elections. The data collection was conducted by the research firm Synovate. A massive number of people were contacted via mail and asked to express their willingness to participate in mail, telephone, or online surveys, and if so, to provide basic demographic information. A balanced sample was then drawn from among the more than 500,000 people who agreed to participate in the prerecruited "mail panel."

In order to ensure representativeness, the sample for the current survey was drawn to reflect demographic distributions within the five Census divisions of household income, population density, panel member's age, gender, and region. This stratified quota sampling method was used to select approximately 2,000 mail survey respondents, from which 777 usable responses were received. This represents a response rate of $38.9 \%$. This stratified quota sampling method differs markedly from more conventional probability sample procedures yet produces highly comparable data (Putnam, 2000; Putnam \& Yonish, 1999).

Demographic characteristics of the current sample resemble the profiles of the national population figures reported in U.S. Census Bureau's 2006 American 
Community Survey (ACS), with respect to age (the median age in the 2006 ASC and the current study is 35-44 and 35, respectively), education attainment (the median education level in both data sets is some college), and household income (the median in the ACS and the current study is $\$ 48,451$ and $\$ 50,000-59,999$, respectively). However, there is a greater percentage of male respondents in the sample (56.2\%) than in the ACS (49.2\%).

\section{Operationalization}

Civic engagement

Five measures were used to tap respondents' involvement in volunteer and community activities: doing volunteer work, working on a community project, contributing money to a social group or cause, going to a community or neighborhood meeting, and working on behalf of a social group or cause (Kwak et al., 2004; Putnam, 2000; Shah, 1998; Shah et al., 2001). Respondents were asked to report how frequently in the past 2 months they participated in a respective activity. An 8-point scale, ranging from "none in the last 2 months" to "everyday," was used, and the responses were combined to form an index $(M=1.83, S D=1.03$, Cronbach $\alpha=.81)$.

\section{Political participation}

Respondents were asked about three types of involvement in traditional forms of political participation: attending a political meeting, rally, or speech; circulating a petition for a candidate or issue; and contacting a public official or a political party (McLeod et al., 1999; Milbraith \& Goel, 1971; Xenos \& Moy, 2007). Respondents reported the frequency of involvement in each type of participation in the past 2 months on an 8-point scale, ranging from none in the last 2 months to everyday. The responses were summed to form an additive index $(M=1.25, S D=.68$, Cronbach $\alpha=.85)$.

\section{Mobile phone use}

Guided by previous U\&G studies of the Internet and mobile phone (Shah et al., 2001; Wei \& Lo, 2006), 14 items were developed to assess mobile phone usage patterns for this study. A factor analysis (principal component, direct Oblimin) was conducted using these items (see Table 1). Each item was recorded on a 7-point scale, which measured how many days in a typical week respondents used their mobile phone for a respective activity. Among users, there are notable differences in mobile activities. For example, among the most popular mobile activities were calling friends or family (93.4\% reported having used their phone for this use at least once a week), using text/instant messages to interact with friends or family (27.8\%), and e-mailing friends or family $(10.3 \%)$. However, some mobile activities were considerably less popular: only $2-4 \%$ of the mobile phone users went online to express their opinions about issues, to read the opinions of others, or to share content about hobbies or personal interests at least once a week.

As shown in Table 1, the factor analysis uncovered a three-factor solution. Personal recreation consists of six items, each of which taps use of the mobile phone 
Table 1 Factor Analysis of Mobile Phone Use Items

\begin{tabular}{|c|c|c|c|}
\hline Item & $\begin{array}{l}\text { Personal } \\
\text { Recreation }\end{array}$ & Sociability & $\begin{array}{l}\text { Information } \\
\text { Exchange }\end{array}$ \\
\hline Go online to share content that is entertaining & .88 & -.01 & -.04 \\
\hline Browse web just for fun & .84 & .12 & .11 \\
\hline $\begin{array}{l}\text { Go online to share content about hobbies or } \\
\text { personal interests }\end{array}$ & .83 & .05 & .11 \\
\hline $\begin{array}{l}\text { Go online to upload content that is mostly just } \\
\text { for fun }\end{array}$ & .76 & -.05 & -.23 \\
\hline $\begin{array}{l}\text { Go online for games and other forms of } \\
\text { entertainment }\end{array}$ & .67 & -.06 & -.15 \\
\hline $\begin{array}{l}\text { Go online to get information about hobbies or } \\
\text { personal interests }\end{array}$ & .60 & .23 & -.16 \\
\hline Call friends or family & -.02 & .79 & .05 \\
\hline $\begin{array}{l}\text { Use text/instant messages to interact with } \\
\text { friends or family }\end{array}$ & .12 & .78 & .00 \\
\hline E-mail friends or family & .25 & .51 & -.15 \\
\hline Go online to express my opinions about issues & .23 & -.16 & -.83 \\
\hline Go online to share news items & .10 & -.12 & -.81 \\
\hline $\begin{array}{l}\text { Use text/instant messages to discuss political } \\
\text { matters }\end{array}$ & -.07 & .16 & -.80 \\
\hline $\begin{array}{l}\text { Go online to read opinions of others regarding } \\
\text { issues }\end{array}$ & .30 & -.18 & -.76 \\
\hline Call others to discuss political matters & -.18 & .33 & -.64 \\
\hline Eigenvalues & 6.16 & 1.62 & 1.53 \\
\hline
\end{tabular}

Notes: Bold items indicate factor loadings $>.50$. Total variance accounted for $66.5 \%$.

for personal hobbies, interests, and entertainment (Cronbach $\alpha=.88$ ). Sociability is comprised of a three-item index that reflects use of the mobile for interacting with friends or family (Cronbach $\alpha=.62$ ). Finally, information exchange is a fiveitem index that measures use of the mobile phone for expressing, discussing, and exchanging opinions about issues (Cronbach $\alpha=.81$ ).

\section{Perceived competence with mobile telephony}

Drawing from previous research (Campbell \& Russo, 2003), items were developed to measure the extent to which participants were comfortable with various features of their mobile phone. Respondents were asked to state how much they agreed with each of the three statements: "I find the special features on my mobile phone difficult to use," "I think my mobile phone is easy to operate," and "I am comfortable with the technical features of my mobile phone." A 6-point response scale, ranging from definitely disagree to definitely agree was used. Responses to the first statement were reverse-coded, and an additive index was created $(M=4.28, S D=1.43$, Cronbach $\alpha=.83$ ). 


\section{Communication variables}

Three measures were employed to reflect respondents' use of traditional news media and their interpersonal communication about political issues, because these communication variables may be related to both mobile phone use and the criterion variables. Past research has shown that political talk tends to foster participation in public affairs (Kwak, Williams, Wang, \& Lee, 2005), and it is plausible that those who are more involved in mass-mediated and interpersonal communication tend to be more active in using their mobile. For television news use, respondents were asked how often they watched national nightly news and local news programs. A 5-point scale, ranging from never to regularly, was used, and the responses were added as an index $(M=3.54, S D=1.26$, interitem correlation $=.62)$. For newspaper use, a single item, which asked about respondent' use of daily newspapers on the same 5-point scale, was used. For political talk, three items that asked respondents to report how frequently during the past 2 months they had talked about politics with neighbors, friends, or family $(M=3.59, S D=1.43$, Cronbach $\alpha=.84)$.

\section{Control variables}

As control variables, this study included age, gender, education, household income, and political interest, which have been found to influence the criterion variables (Jeffres, Atkin, \& Neuendorf, 2002; Shah et al., 2001, 2005). To measure political interest, respondents were asked to state how much they agreed with the following statement, "I am interested in politics," on a 6-point scale, ranging from definitely disagree to definitely agree $(M=3.50, S D=1.72)$.

\section{Interaction terms}

In order to carry out analyses corresponding to RQ3, this study created interaction terms between the different usage patterns and competence with mobile telephony. To reduce potential problems with multicollinearity between interaction terms and their components, all the component variables were standardized prior to the formation of the interaction terms (Cronbach, 1987; Eveland, 1997; Jaccard, Turrisi, \& Wan, 1990).

\section{Results}

Table 2 shows findings for $\mathrm{H} 1, \mathrm{RQ} 1$, and $\mathrm{H} 2$, each of which concerns the relationship between use of the mobile phone and the criterion variables (see Table 3 for correlations among all measures). A hierarchical regression was separately run for each of the two participation variables: civic engagement and political participation. As shown in Table 2, among the control variables, female and higher educated respondents were found to be more civically engaged, and those with greater interest in politics demonstrated greater participation in political events and opportunities. Among the communication variables, political talk was significantly related to both criterion variables. Overall, the control block accounted for 8.0 and $11.0 \%$ of 
Table 2 Predictors of Engagement

\begin{tabular}{|c|c|c|c|c|}
\hline & \multicolumn{2}{|c|}{ Civic Engagement } & \multicolumn{2}{|c|}{ Political Participation } \\
\hline & $\beta$ & $t$ Value & $\beta$ & $t$ Value \\
\hline \multicolumn{5}{|l|}{ Control variables } \\
\hline Age & .05 & 1.20 & -.06 & -1.40 \\
\hline Gender (high: female) & $.09^{*}$ & 2.19 & .01 & .25 \\
\hline Education & $.14^{* *}$ & 3.20 & .05 & 1.37 \\
\hline Household income & .01 & .33 & -.02 & -.56 \\
\hline Political interest & .01 & .31 & $.11^{* *}$ & 2.71 \\
\hline$R^{2}(\%)$ & \multicolumn{2}{|c|}{$8.0^{* * *}$} & \multicolumn{2}{|c|}{$11.0^{* *}$} \\
\hline \multicolumn{5}{|l|}{ Communication variables } \\
\hline Newspaper use & -.01 & -.23 & .02 & .47 \\
\hline Television news use & -.01 & -.29 & .04 & 1.15 \\
\hline Political talk & $.24^{* *}$ & 5.03 & $.29^{* *}$ & 6.90 \\
\hline Incremental $R^{2}(\%)$ & \multicolumn{2}{|c|}{$5.8^{* *}$} & \multicolumn{2}{|c|}{$9.9^{* *}$} \\
\hline \multicolumn{5}{|l|}{ Mobile phone use } \\
\hline Information exchange & $.15^{* *}$ & 2.80 & $.27^{* *}$ & 5.81 \\
\hline Sociability & .04 & .94 & -.06 & -1.34 \\
\hline Personal recreation & $.09 \#$ & 1.85 & $.14^{* *}$ & 3.05 \\
\hline Incremental $R^{2}(\%)$ & \multicolumn{2}{|c|}{$5.1^{* *}$} & \multicolumn{2}{|c|}{$12.2^{* *}$} \\
\hline Final $R^{2}(\%)$ & \multicolumn{2}{|c|}{$18.9^{* *}$} & \multicolumn{2}{|c|}{$33.2^{* *}$} \\
\hline
\end{tabular}

Note: Entries are standardized regression coefficients.

$\# p<.10 ;{ }^{*} p<.05 ;{ }^{* *} p<.01$.

the variance in civic engagement and political participation, respectively, and the communication block additionally explained 5.8 and $9.9 \%$.

As a block, mobile phone use accounted for 5.1 and $12.2 \%$ of the variance in civic engagement and political participation, respectively, after the contribution of the prior two blocks was taken into consideration. As expected (H1), use of mobile telephony for discussing and exchanging opinions on issues was significantly and positively related to both participation measures $(\beta=.15$ for civic engagement, and $\beta=.27$ for political participation). In fact, among the three dimensions of mobile phone use, information exchange was found to have the strongest relationship with the criterion variables. However, the findings show that there was little relationship between mobile sociability and participation (RQ1). Contrary to H2, use of the mobile phone for personal recreation was positively and significantly related to political participation $(\beta=.14)$ and civic engagement $(\beta=.09)$, the latter of which was only marginally significant, though.

Although the analyses reported in Table 2 examined the direct relationship between mobile phone use and public affairs participation, those in Table 4 further investigated whether the consideration of perceived competence with mobile telephony would permit more nuanced understanding. After the control, of the three 


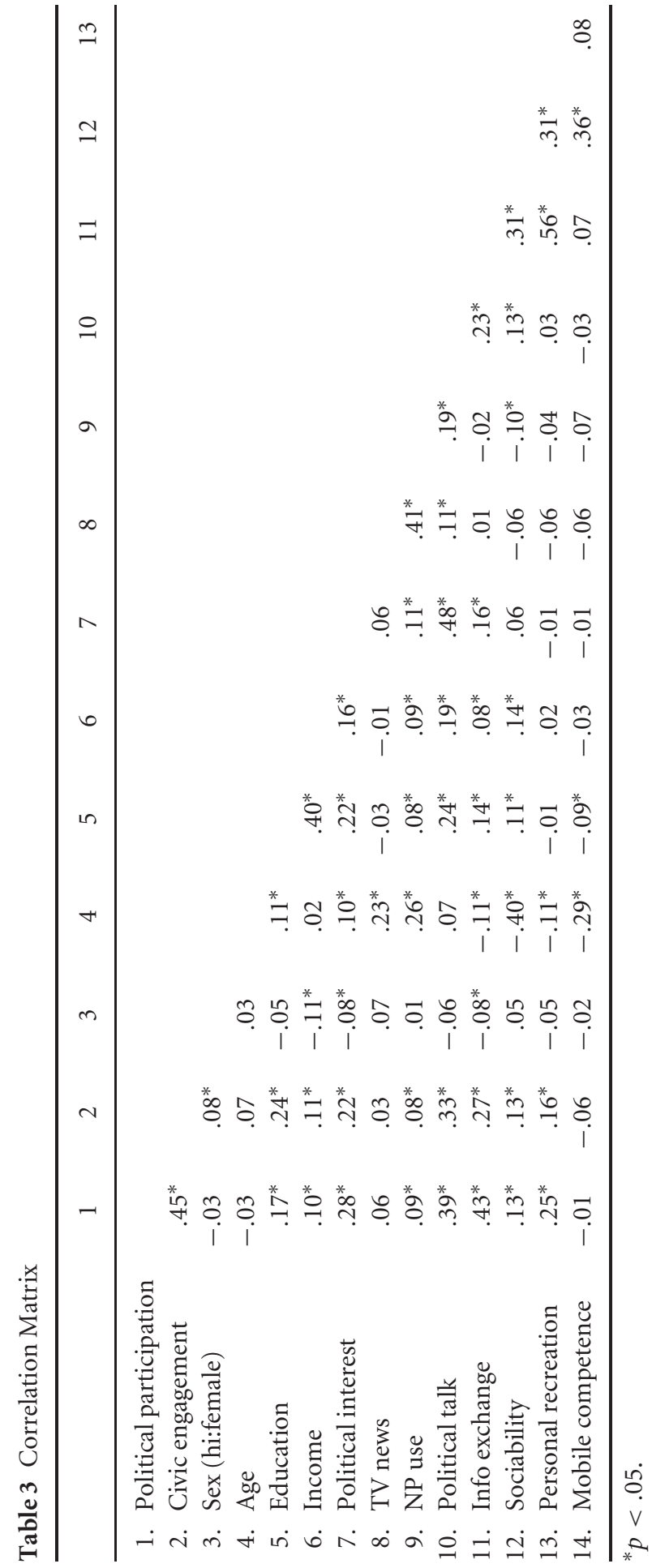


Table 4 Interactive Relationships Between Mobile Phone Use and Perceived Competence with Mobile Telephony

\begin{tabular}{|c|c|c|c|c|}
\hline & \multicolumn{2}{|c|}{ Civic Engagement } & \multicolumn{2}{|c|}{ Political Participation } \\
\hline & $\beta$ & $t$ Value & $\beta$ & $t$ Value \\
\hline Prior blocks $\left(R^{2}, \%\right)$ & \multicolumn{2}{|c|}{$20.5^{* *}$} & \multicolumn{2}{|c|}{$35.3^{* *}$} \\
\hline \multicolumn{5}{|l|}{ Interaction terms } \\
\hline $\begin{array}{l}\text { Information exchange } \times \text { Perceived } \\
\text { competence }\end{array}$ & $.16^{* *}$ & 2.81 & $.14^{* *}$ & 2.64 \\
\hline $\begin{array}{l}\text { Sociability } \times \text { Perceived } \\
\text { competence }\end{array}$ & -.02 & -.44 & -.02 & -.55 \\
\hline $\begin{array}{l}\text { Personal recreation } \times \text { Perceived } \\
\text { competence }\end{array}$ & -.07 & -1.08 & $-.10 \#$ & -1.76 \\
\hline Incremental $R^{2}(\%)$ & \multicolumn{2}{|c|}{$3.2^{* *}$} & \multicolumn{2}{|c|}{$3.1^{* *}$} \\
\hline Final $R^{2}(\%)$ & \multicolumn{2}{|c|}{$23.7^{* *}$} & \multicolumn{2}{|c|}{$38.4^{* *}$} \\
\hline
\end{tabular}

Notes: Prior blocks include age, gender, education, household income, political interest, and newspaper news use, television news use, political talk, and perceived competence with mobile telephony. Entries are standardized regression coefficients after the control.

$\# p<.10 ;{ }^{*} p<.05 ;{ }^{* *} p<.01$.

interaction terms one variable, Information exchange $\times$ Perceived competence, was found to be significant in both regression equations. Interestingly, this particular dimension of mobile phone use is the one that demonstrated a significant relationship with both criterion variables (see Table 2), which thus indicates that the inclusion of perceived confidence as a moderator tended to further specify the relationships.

In order to understand the significant interactive relationships, predicated values of civic engagement and political participation were plotted in Figure 1. For both criterion variables, four groups that had different degrees of mobile phone use for information exchange were identified with respect to how frequently they used a mobile phone to express, discuss, or exchange opinions about issues: none, once a week, three times a week, and seven times a week. Then, for each frequency group, participation scores for three levels of perceived competence with mobile communication technologies (low, medium, and high) were computed and plotted. ${ }^{1}$

Similar patterns of the relationships were shown for civic engagement and political participation. While the findings in Table 2 indicate a positive relationship between use of the mobile phone for information exchange and both participation variables, the results in the figure demonstrate that the positive relationships tended to become stronger as people became more familiar and felt competent with various technological features of their mobile phone. Also noteworthy is that the positive relationship between information exchange and participation was non-existent among those whose perceived competence with mobile technologies was low. In particular, the positive relationship between information exchange and civic 
Civic Engagement

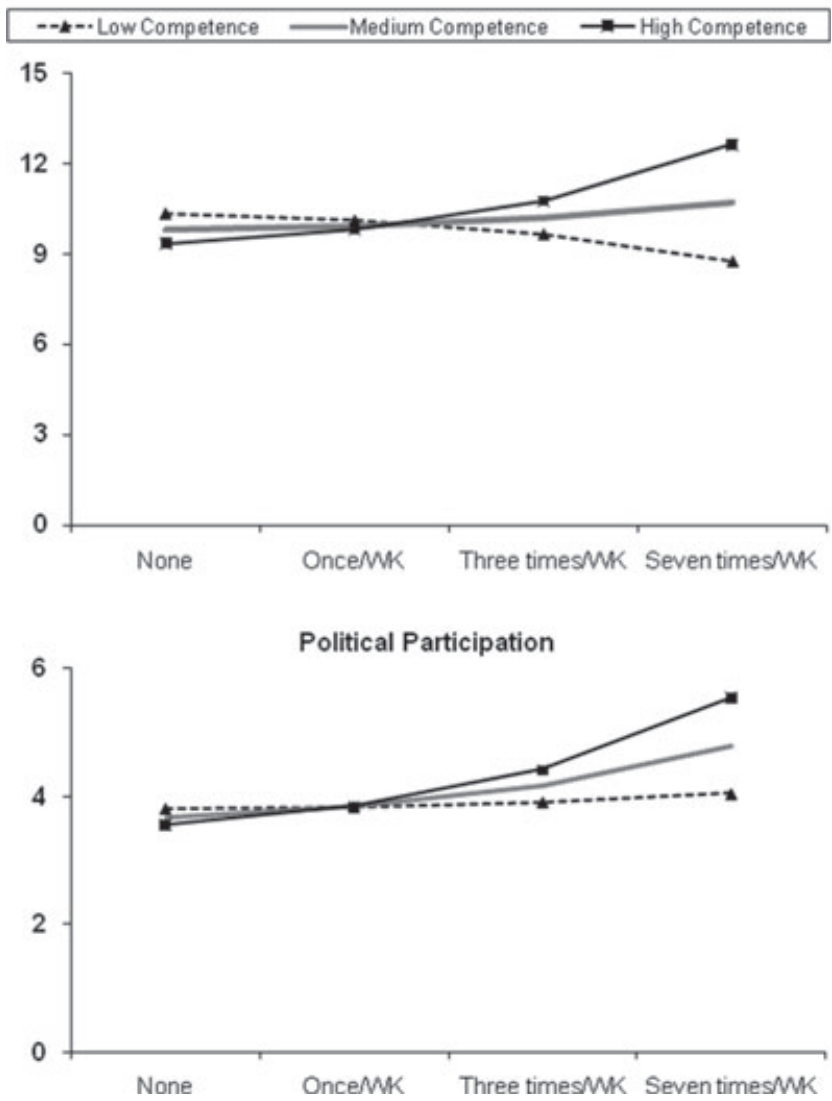

Figure 1 Predicting criterion variables with mobile-mediated Information exchange $\times$ Competence with mobile telephony.

engagement (top of Figure 1) appears to be manifested mostly among those who were highly at ease utilizing features of mobile telephony.

\section{Discussion}

This study examined how patterns of mobile communication may either support or hinder engagement in the civic and political spheres of social life. As expected, results revealed a positive main relationship between mobile phone use for information exchange and civic and political involvement. Past studies have also found that use of the Internet for this purpose fosters engagement in civic life (Shah et al., 2001), and the findings from this study thus indicate a consistent trend for use of mobile communication technology. Explanation for this trend may lie in the shared affordances of these technologies. Wellman et al. (2003) highlight a number of social affordances of the computer-based Internet that support attachment to others and 
their community. These affordances include multiple channels for interaction and data exchange, perpetual and globalized connectivity, personalization, and wireless portability. Although harnessed in different ways, many of the social affordances of the mobile phone parallel those of the computer-based Internet. Thus, both mobile and Internet technologies lower the threshold for communication, which, as this and previous research suggests, offers significant social capital benefits when used for informational purposes.

Although the results highlight benefits of mobile-mediated information exchange for civic and political engagement, they also illustrate that these benefits are not uniformly accessible. Individuals who feel more comfortable using mobile telephony and use it for exchanging information about public affairs tend to be more civically and politically engaged than those who are less comfortable with the technology. This finding underscores an emergent dimension of the digital divide - technological fluency. Hargittai (2002) argues that beyond the traditional divide between haves and have-nots, researchers should also be concerned with a "second-level" digital divide in the form of online skills, particularly as they apply to using computers to search for, access, and exchange information over the Internet. The core argument here is that increased skill at information exchange through the computer contributes to increased opportunity and engagement in society (DiMaggio, Hargittai, Celeste, \& Shafer, 2004; Hargittai, 2002). The results of this study support this argument while extending it to the context of mobile communication technology.

Extending this "second-level" digital divide to mobile telephony will become even more important as the technology continues to develop from a resource primarily used for point-to-point interpersonal contact into a multifaceted tool for information access, distribution, and management. The evolution of the mobile phone into a sophisticated computer-like device is evident through wireless innovations such as the BlackBerry, T-Mobile's Sidekick, and Apple's iPhone. The future offers continued development and opportunities for customization through open-source platforms such as Google and partners' gPhone application. To be sure, the rapid evolution of mobile communication technology creates new affordances for people to be connected and informed, however it also poses new challenges for those with lower levels of technological fluency, and this can have a detrimental effect on one's ability to maximize the benefits of mobile communication technology.

Although the present findings for information exchange are consistent with previous research on the Internet, those for recreational use are notably different. Mobile-mediated recreation was positively associated with social capital indicators, whereas such use has yielded negative associations in previous research on the Internet (Shah et al., 2001). One plausible explanation for this discrepancy may be the heightened degree of personalization associated with mobile telephony. Mobile communication is the embodiment of personalization because it tends to involve contact with known others with fixed and identifiable account numbers. Although CMC may also be personalized in this sense, it is frequently used for anonymous interactions among unknown others with fluid screen names, especially 
in a recreational context. It is possible that the heightened degree of personalization associated with mobile communication fosters more accountability and prosocial behavior than anonymous interaction online, leading to increased trust in others and civic-mindedness. While this conclusion is speculative, it is supported by the fact that recreational use of the Internet in Shah et al.'s study tended to involve anonymous communication, which consistently yielded negative associations with social capital indicators.

Several of the items that comprise recreation in this study assess the extent to which participants use mobile technology to obtain and share content pertaining to hobbies, personal interests, and fun. These types of activities involve an exchange with others who share similar interests, and resonate with social capital benefits of informational and communicative media use discussed by Norris and Jones (1998). It is possible that mobile-mediated recreational exchanges engender a community of practice that provides a space for expression and exposure to perspectives on civic and political matters, especially if those matters are germane to the personal interests and hobbies of the users. One way of testing this interpretation is to examine age-related patterns in the links between mobile phone use for recreation and involvement in public life. Research shows that older adults tend to have greater involvement in public affairs than younger individuals (Quintelier, 2007). Accordingly, one might expect age to interact with mobile phone use for personal recreation such that the positive associations between recreational use and engagement would be stronger for older adults, whose personal interests and hobbies are more likely to touch on civic and political matters. To examine this, we ran post hoc regression analyses using age as a moderating variable, which yielded significant results for recreation (see Table 5). ${ }^{2}$ Indeed, as age increases, the associations between use for recreation and participation in civic life become stronger, suggesting that this form of mobile communication is a more valuable resource for public involvement among the older

Table 5 Interactive Relationships Between Mobile Phone Use and Age

\begin{tabular}{|c|c|c|c|c|}
\hline & \multicolumn{2}{|c|}{ Civic Engagement } & \multicolumn{2}{|c|}{ Political Participation } \\
\hline & $\beta$ & $t$ Value & $\beta$ & $t$ Value \\
\hline Prior blocks $\left(R^{2}, \%\right)$ & \multicolumn{2}{|c|}{$18.9^{* *}$} & \multicolumn{2}{|c|}{$33.2^{* *}$} \\
\hline \multicolumn{5}{|l|}{ Interaction terms } \\
\hline Information exchange $\times$ Age & -.00 & -.04 & -.07 & .94 \\
\hline Sociability $\times$ Age & .02 & .32 & -.05 & -1.33 \\
\hline Personal recreation $\times$ Age & $.16^{* *}$ & 2.80 & $.12^{*}$ & 2.29 \\
\hline Incremental $R^{2}(\%)$ & \multicolumn{2}{|c|}{$1.2^{*}$} & \multicolumn{2}{|c|}{$1.2^{*}$} \\
\hline Final $R^{2}(\%)$ & \multicolumn{2}{|c|}{$20.1^{* *}$} & \multicolumn{2}{|c|}{$34.5^{* *}$} \\
\hline
\end{tabular}

Notes: Prior blocks include age, gender, education, household income, political interest, and newspaper news use, television news use, and political talk. Entries are standardized regression coefficients after the control.

$\# p<.10 ;{ }^{*} p<.05 ;{ }^{* *} p<.01$. 
population of users. In fact, recreation is the only dimension of mobile phone use in this study for which age yields a significant interaction effect, revealing a distinctive trend in the intersections between mobile communication, age, and civic/political engagement. These findings are particularly interesting considering the Internet tends to be a more useful resource for civic engagement among younger users than older adults (Shah et al., 2001).

In addition to the significant results, it is also worth noting that no main effects were found for mobile-mediated sociability, possibly indicating that this form of use may be a distinctively private activity with limited implications for civic life. However, we are hesitant to accept this conclusion without acknowledging that mobile-mediated sociability can take on many forms beyond the measure used for this study, which broadly assessed weekly contact with friends and family. This may explain its relatively low reliability coefficient (Cronbach $\alpha=.62$ ) and possibly the lack of significance. Indeed, a more nuanced and robust account of mobile-mediated sociability may reveal significant and differential effects on engagement in civic life, and follow-up investigations should offer a more fine-grained analysis of how the technology is used in practice.

Future research should also account for the nature of social contacts involved in mobile-mediated exchanges. Social network characteristics have a particularly important influence on patterns of mobile phone use (Campbell \& Russo, 2003), which may in turn influence civic and political involvement. One can argue that members of large, heterogeneous social networks are exposed to more diverse social perspectives and deliberation than those who typically interact within a small, insular network of close ties. With a few notable exceptions (Boase \& Kobayashi, 2008; Humphreys, 2007; Humphreys \& Barker, 2007), the selectivity associated with mobile communication is believed to support and strengthen existing ties rather than build new ones (Ling, 2008; Matsuda, 2005). de Gournay (2002) even argues that mobile communication fosters a decrease in social ties as networks become less diffuse and more tight-knit. Gergen (2008) characterizes this trend as "monadic clustering" and theorizes it can have negative consequences for civil society when networks become insular and detached from the democratic process. Therefore, future studies in this area should explore how mobile phone use intersects with social network characteristics — such as size, integration, and homogeneity - and how those characteristics might influence engagement in civic life.

In addition to the perils of mobile-mediated insularity, future investigations should also explore the promises of technological convergence for civic and political engagement. An increasing number of individuals are using the mobile Web in ways that can have implications for civic life. One notable example is the growing phenomenon of Moblogs or regularly updated Web publications which are created and maintained with mobile devices. We have only just begun to see the extent to which and how mobile communication technology can be used as an Internet resource, which will open new avenues for research on the role that it plays in civic and political engagement. 
The findings from this study help answer some questions about mobile communication and civic life while paving the way for follow-up investigations. However, these contributions must be qualified by some limitations. First, it is possible that the control variable of political talk is somewhat confounded with the engagement variables. Although treated as conceptually distinct in previous research (Kwak et al., 2005), those who participate in civic and political activities may also be likely to talk about politics with others during their involvement, thus it is important for future research to examine recursive relationships between political talk via various channels and participation. Another limitation pertains to the scope of the study. Because it was designed as foundational work that loosely replicates previous research on Internet use and social capital, predictor variables were limited to mobile-mediated information exchange, sociability, and recreation. Furthermore, because these measures were arrived at through factor analysis, only broad usage trends were examined in this study. Future research will benefit from a more detailed account of how mobile communication practices are associated with involvement in civic life. Criterion variables of interest were limited as well, and future investigations should broaden social capital indicators to include various forms of informal social activity and interpersonal trust, in addition to civic and political engagement (Putnam, 2000). Finally, because the survey data are cross-sectional in nature, associations must be qualified as correlational. We are unable to infer whether mobile communication actually influences civic and political engagement, or whether the causal arrow flows in the other direction. While this investigation may not provide firm grounds for causal claims, it does offer new empirical evidence that certain patterns of mobile communication at least support civic and political engagement, particularly for those who feel comfortable using the technology.

\section{Notes}

1 For the medium competence group, the mean value of the variable was assigned; for the high and low competence groups, the values one standard deviation higher and lower than the mean, respectively, were used. For the other variables in the model, mean values were assigned. For gender, female category was chosen.

2 Following a reviewer's suggestion, we created various age groups: first, three subgroups that reflect place in life cycle (18-29,30-49, and 50 or older), and second, three generational cohorts (Generation-Y, Generation-X, and Baby Boomer or older). Regression analyses within each group yielded patterns similar to those in Table 5. Use of mobile phone for sociability was not a significant predictor in any of the analyses, while personal recreational was significant for both civic engagement and political participation among older age groups. Since the life cycle and generational categories partly overlap, when considered together, the analyses uncovered some interesting findings. Use of the mobile phone for information exchange was significant among $18-29$ olds, but was not significant among Generation Yers (18-24), suggesting that the significant role of informational use of the mobile phone may be limited to those who were mid- to late-20s at the time of the survey. Similarly, informational use of the mobile 
phone was significant among Generation-Xers (aged 25-41), but was not significant among 30-49 olds from the life cycle group. Again, these findings suggest that mobile informational exchange might be particularly significant among those who were in midto late-20s at the time of the survey. Such inferences should be taken with care in the context of the current study, although, because the size of some subgroups was too small to draw conclusions. However, these findings certainly encourage future research to examine carefully the role of mobile telephony in different life cycle groups or generational cohorts.

\section{References}

Besley, J. C. (2006). The role of entertainment television and its interactions with individual values in explaining political participation. The Harvard International Journal of Press/Politics, 11(2), 41-63.

Blumler J. G., \& Katz, E. (Eds.) (1974). The uses of mass communications: Current perspectives on gratifications research. Beverly Hills, CA: Sage.

Boase, J., \& Kobayashi, T. (2008). Kei-Tying teens: Using mobile phone e-mail to bond, bridge, and break with social ties - A study of Japanese adolescents. International Journal of Human-Computer Studies, 66, 930-943.

Campbell, S. W., \& Kwak, N. (2010). Mobile communication and social capital: An investigation of geographically differentiated usage patterns. New Media and Society, 12, 435-451.

Campbell, S. W., \& Neer, M. R. (2001). The relationship of communication apprehension and interaction involvement to perceptions of computer-mediated communication. Communication Research Reports, 18(4), 391-398.

Campbell, S. W., \& Park, Y. J. (2008). Social implications of mobile telephony: The rise of personal communication society. Sociology Compass, 2, 371-387. doi: 10.1111/ j.1751-9020.2007.00080.x

Campbell, S. W., \& Russo, T. C. (2003). The social construction of mobile telephony: An application of the social influence model to perceptions and uses of mobile phones within personal communication networks. Communication Monographs, 70, 317-334.

Castells, M., Fernandez-Ardevol, M., Qiu, J., \& Sey, A. (2007). Mobile communication and society: A global perspective. Cambridge, MA: MIT Press.

Charney, T., \& Greenberg, B. (2002). Uses and gratifications of the Internet. In C. Lin \& D. Atkin (Eds.), Communication, technology and society: New media adoption and uses (pp. 383-406). Cresskill, NJ: Hampton.

Cho, J., Rojas, H., \& Shah, D. V. (2003). Social capital and media. In K. Christensen \& D. Levinson (Eds.), Encyclopedia of community: From the village to the virtual world (pp. 1291-1295). Thousand Oaks, CA: Sage.

Cronbach, L. J. (1987). Statistical tests for moderator variables: Flaws in analyses recently proposed. Psychological Bulletin, 102, 414-417.

Coleman, J. S. (1990). Foundations of social theory. Cambridge, MA: Harvard University Press.

de Gournay, C. (2002). Pretense of intimacy in France. In J. Katz \& M. Aakhus (Eds.), Perpetual contact: Mobile communication, private talk, public performance (pp. 193-205). Cambridge, U.K.: Cambridge University Press. 
December, J. (1996). Units of analysis for Internet communication. Journal of Communication, 46, 14-38.

DiMaggio, P., Hargittai, E., Celeste, C., \& Shafer, S. (2004). Digital inequality: From unequal access to differentiated use. In K. Neckerman (Ed.), Social inequality (pp. 355-400). New York: Russell Sage Foundation.

Dimmick, J. W., Sikand, J., \& Patterson, S. J. (1994). The gratifications of the household telephone: Sociability, instrumentality, and reassurance. Communication Research, 21, 643-663.

Eighmey, J., \& McCord, L. (1998). Adding value in the information age: Uses and gratifications of sites on the World-Wide Web. Journal of Business Research, 41(1), 87-194.

Eveland, W. P., Jr. (1997). Interactions and nonlinearity in mass communication: Connecting theory and methodology. Journalism and Mass Communication Quarterly, 74, 400-416.

Finn, S. (1997). Origins of media exposure: Linking personality traits to TV, radio, print, and film use. Communication Research, 24, 507-529.

Gergen, K. J. (2008). Mobile communication and the transformation of the democratic process. In J. Katz (Ed.), Handbook of mobile communication studies (pp. 297-310). Cambridge, MA: MIT Press.

Habuchi, I. (2005). Accelerating reflexivity. In M. Ito, D. Okabe \& M. Matsuda (Eds.), Personal, portable, pedestrian: Mobile phones in Japanese Life (pp. 165-182). Cambridge, MA: MIT Press.

Hacker, K., \& Steiner, R. (2001). Hurdles of access and benefits of usage for Internet communication. Communication Research Reports, 18, 399-407.

Hampton, K., \& Wellman, B. (2001). Long distance community in the network society: Contact and support beyond Netville. American Behavioral Scientist, 45(3), 476-495.

Hargittai, E. (2002). Second-level digital divide: Differences in people's online skills. First Monday, 7(4). Retrieved July 28, 2010, from http://firstmonday.org/htbin/cgiwrap/bin/ ojs/index.php/fm/article/view/942/864

Humphreys, L. (2007). Mobile social networks and social practice: A case study of Dodgeball. Journal of Computer-Mediated Communication, 13(1). Retrieved March 22, 2008, from http://jcmc.indiana.edu/vol13/issue1/humphreys.html

Humphreys, L., \& Barker, T. (2007). Modernity and the mobile phone: Exploring tensions about dating and sex in Indonesia. Journal of Media \& Culture, 10(1). Retrieved March 22, 2008, from http://journal.media-culture.org.au/0703/06-humphreys-barker.php

Jaccard, J., Turrisi, R., \& Wan, C. K. (1990). Interaction effects in multiple regression. Newbury Park, CA: Sage.

Jeffres, L. W., Atkin, D., \& Neuendorf, K. A. (2002). A model linking community activity and communication with political attitudes and involvement in neighborhoods. Political Communication, 19, 387-421.

Katz, E., Blumler, J. G., \& Gurevitch, M. (1974). Utilization of mass communication by the individual. In J. Blumler \& E. Katz (Eds.), The uses of mass communications: Current perspectives on gratifications research (pp. 19-32). Beverly Hills, CA: Sage.

Kaye, B. K. (1998). Uses and gratifications of the World Wide Web: From couch potato to Web potato. The New Jersey Journal of Communication, 6(1), 21-40.

Kraut, R. E., Patterson, M., Lundmark, V., Kiesler, S., Mukhopadhyay, T., \& Scherlis, W. (1998). Internet paradox: A social technology that reduces social involvement and psychological well-being? American Psychologist, 53(9), 1017-1032. 
Kwak, N., Shah D. V., Holbert, R. L. (2004). Connecting, trusting, and participating: The direct and interactive effect of social associations. Political Research Quarterly, 57(4), $643-652$.

Kwak, N., Williams, A., Wang, X., \& Lee, H. (2005). Talking politics and engaging politics: An examination of the interactive relationships between structural features of political talk and discussion engagement. Communication Research, 32, 87-111.

LaRose, R. L., Eastin, M., \& Gregg, J. L. (2001). Reformulating the internet paradox: Social cognitive explanations of internet use and depression. Journal of On-line Behavior, 1(2). Retrieved July 28, 2010, from http://behavior.net/JOB/v1n2/paradox.html

LaRose, R., \& Mettler, J. (1990). User responses to custom local area signaling services: A survey and field experiment. Paper presented at the 40th annual conference of the International Communication Association, June, Dublin, Ireland.

Leung, L., \& Wei, R. (2000). More than just talk on the move: Uses and gratifications of the cellular phone. Journalism and Mass Communication Quarterly, 77(2), 308-320.

Ling, R. (2004). The mobile connection: The cell phone's impact on society. San Francisco: Morgan Kaufman.

Ling, R. (2008). New tech, new ties: How mobile communication is reshaping social cohesion. Cambridge, MA: MIT Press.

Ling, R., Yttri, B., Anderson, B., \& DiDuca, D. (2003). Mobile communication and social capital in Europe. In K. Nyiri (Ed.), Mobile democracy: Essays on society, self, and politics. Vienna: Passagen Verlag.

Matsuda, M. (2005). Mobile communication and selective sociality. In M. Ito, D. Okabe, \& M. Matsuda (Eds.), Personal, portable, pedestrian: Mobile phones in Japanese life (pp. 123-142). Cambridge, MA: MIT Press.

McLeod, J. M., Daily, K., Guo, Z., Eveland, W. P., Jr., Bayer, J., Yang, S., et al. (1996). Community integration, local media use and democratic processes. Communication Research, 23, 179-209.

McLeod, J. M., Scheufele, D. A., \& Moy, P. (1999). Community, communication, \& participation: The role of mass media and interpersonal discussion in local political participation. Political Communication, 16, 315-336.

McQuail, D. (1983). Mass communication theory. London: Sage.

Milbraith, L., \& Goel, M. (1971). Political participation (2nd ed.) Chicago: Rand McNally.

Newton, K. (1997). Social capital and democracy. The American Behavioral Scientist, 40, $575-586$.

Nie, N. H., \& Erbring, L. (2002). Internet and society: A preliminary report. IT \& Society, 1(1): 275-283. Retrieved February 1, 2006, from http://www.stanford.edu/group/ siqss/itandsociety/v01i01/v01i01a18.pdf

Norris, P. (1996). Does television erode social capital? A reply to Putnam. PS: Political Science and Politics, 29(3), 474-480.

Norris, P., \& Jones, D. (1998). Virtual democracy. Harvard International Journal of Press/Politics, 3(2), 1-4.

O'Keefe, G. J., \& Sulanowski, B. K. (1995). More than just talk: Uses, gratifications, and the telephone. Journalism and Mass Communication Quarterly, 72, 922-933.

Papacharissi, Z., \& Rubin, A. M. (2000). Predictors of Internet Use. Journal of Broadcasting \& Electronic Media, 44, 175-196.

Perse, E. M., \& Ferguson, D. A. (2000). The benefits and costs of Web surfing. Communication Quarterly, 48, 343-359. 
Putnam, R. D. (1995a). Bowling alone: America's declining social capital. Journal of Democracy, 6(1), 65-78.

Putnam, R. D. (1995b). Tuning in, tuning out: The strange disappearance of social capital in America. PS: Political Science and Politics, 28, 664-683.

Putnam, R. D. (2000). Bowling alone: The collapse and revival of American community. New York: Simon \& Schuster.

Putnam, R. D., \& Yonish, S. (1999, May). How important are random samples? Some surprising new evidence. Paper presented to the annual meeting of the American Association of Public Opinion Research, St. Petersburg, FL.

Quintelier, E. (2007). Differences in political participation between young and old people. Contemporary Politics, 13, 165-180.

Shah, D. V. (1998). Civic engagement, interpersonal trust, and television use: An individual-level assessment of social capital. Political Psychology, 19, 469-496.

Shah, D. V., Cho, J., Eveland, W. P., Jr., \& Kwak, N. (2005). Information and expression in a digital age: Modeling internet effects on civic participation. Communication Research, 32, 531-565.

Shah, D. V., Kwak, N., \& Holbert, R. L. (2001). "Connecting” and "disconnecting” with civic life: Patterns of Internet use and the production of social capital. Political Communication, 18, 141-162.

Sotirovic, M., \& McLeod, J. M. (2001). Values, communication behavior, and political participation. Political Communication, 18, 273-300.

Tewksbury, D., \& Althaus, S. L. (2000). An examination of motivations for using the World Wide Web. Communication Research Reports, 17, 127-138.

van Dijk, J. (1999). The network society: Social aspects of new media. London: Sage.

van Dijk, J., \& Hacker, K. (2003). The digital divide as a complex and dynamic phenomenon. The Information Society, 19, 315-326.

Wei, R. (2008). Motivations for using the mobile phone for mass communications and entertainment. Telematics and Informatics, 25(1), 36-46.

Wei, R., \& Lo, V.-H. (2006). Staying connected while on the move: Cell phone use and social connectedness. New Media \& Society, 8(1), 53-72.

Wellman, B., Boase, J., \& Chen, W. (2002). The networked nature of community online and offline. IT \& Society, 1(1), 151-165. Retrieved February 1, 2006, from http://www. stanford.edu/group/siqss/itandsociety/v01i01/v01i01a10.pdf

Wellman, B., Quan-Haase, A., Boase, J., Chen, W., Hampton, K., de Diaz, I. I., et al. (2003). The social affordances of the Internet for networked individualism. Journal of Computer-Mediated Communication, 8(3). Retrieved January 10, 2009, from http://jcmc. indiana.edu/vol8/issue3/wellman.html

Williams, F., Dordick, H., \& Jesuale, N. (1985). Focus group and questionnaire development for exploring attitudes towards telephone service. In F. Williams (Ed.), Social research and the telephone. Los Angeles, CA: Herbert Dordick.

Xenos, M., \& Moy, P. (2007). Direct and differential effects of the Internet on political and civic engagement. Journal of Communication, 57, 704-718. 


\title{
手机传播与公民生活 : 应用与公民和政治参与度的关联模式
}

\author{
Scott W. Campbell \\ Nojin Kwak \\ 密歇根大学传播研究系
}

\begin{abstract}
【摘要 : 】
本研究采用使用与满足的方法来研究手机的使用模式如何与公民和政治参 与度相关联。结果显示, 使用技术来进行信息交流和娱乐与公民生活的参与度呈 正相关，然而，使用手机传播的能力减轻了这种联系。值得注意的是，愿意使用 手机并用其交流信息的人往往比对技术不适的人更积极参与公民和政治事务。该 发现揭示了手机传播在公民社会中的积极作用，同时强调使用能力作为所谓的 “第二级”数字鸿沟的新维度, 以前的研究更关注电脑应用技术。
\end{abstract}


La communication mobile et la vie civique : associer les usages à l'engagement civique et politique

\section{Scott W. Campbell \& Nojin Kwak}

Cette étude a utilisé une approche des usages et gratifications pour investiguer les manières dont les usages de téléphones mobiles sont liés à l'implication civique et politique. Les résultats révèlent que l'usage de la technologie pour l'échange d'informations et la récréation sont des variables explicatives positives de la participation dans la vie civique. Les associations sont toutefois modérées par la compétence en communication mobile. Notamment, les individus qui déclarent de plus haut degrés d'aise avec la téléphonie mobile et qui l'utilisent pour l'échange d'informations tendent à être plus engagés civiquement et politiquement que ceux qui déclarent être moins à l'aise avec la technologie. Ces résultats jettent un nouvel éclairage sur le rôle positif de la communication mobile dans la société civile, tout en soulignant que la compétence est une dimension émergente du soi-disant fossé numérique « de second ordre », qui s'est traditionnellement concentré sur les compétences à l'ordinateur.

Mots clés : communication mobile, téléphone mobile, téléphone cellulaire, capital social, engagement civique, participation politique, usages et gratifications, fossé numérique, facilité technologique 
Mobilkommunikation und bürgerliches Leben: Die Verknüpfung von Nutzungsmustern mit bürgerlichen und politischen Engagement

\section{Scott W. Campbell \& Nojin Kwak}

Die Studie nutzt einen Uses-and-Gratifications-Ansatz, um zu untersuchen, wie Handynutzungsmuster mit bürgerlicher und politischer Teilhabe verknüpft sind. Die Ergebnisse zeigen, dass die Nutzung der Technologie für den Informationsaustausch und Erholung positive Prädiktoren für eine Teilhabe am bürgerlichen Leben sind, wobei die Zusammenhänge durch Handykompetenz moderiert werden. Erwähnenswert ist, dass Teilnehmer, die eine größere Behaglichkeit im Umgang mit Mobiltelefonie angaben und diese für den Informationsaustausch einsetzen, häufiger bürgerlich und politisch involviert waren als jene, die sich unwohler mit der Technologie fühlten. Diese Ergebnisse beleuchten die positive Rolle der Mobilkommunikation in der bürgerlichen Gesellschaft und unterstreichen dabei Kompetenz als die herausragende Dimension der sogenannten digitalen Kluft der zweiten Ebene, welche sonst immer auf Computerfähigkeiten fokussiert hat. 
Mobile Communication and Civic Life:

Linking Patterns of Use to Civic and Political Engagement

모바일 커뮤니케이션과 시민생활:

사용자의 연계 행태들과 정치적 참여도

Scott W. Campbell \& Nojin Kwak

Department of Communication Studies, University of Michigan, Ann Arbor, MI 48104

요약

본연구는 어떻게 모바일사용형태가 시민적 그리고 정치적 관여에 연계되어 있는가를

연구하기 위하여 이용과 만족접근법을 사용하였다. 발견들은 정보교환과 오락을 위한

기술의 사용은 시민생활에서의 참여를 긍적적으로 예측하는 것으로 나타났으나, 그

관계들은 모바일 커뮤니케이션의 능력에 따라 중재된다는 것을 보여주고 있다. 잘

아는바대로, 모바일전화에 대한 만족도가 높고 모바일전화를 정보교환을 위해 사용하는

개인들은 모바일기술에 대한 만족도가 낮은 사람들보다 더욱 시민적으로 그리고

정치적으로 참여도가 높은 것으로 나타났다. 이러한 발견들은 시민사회에서의 모바일

커뮤니케이션의 긍적적인 역할을 지지하는 한편, 전통적으로 컴퓨터 기술에 촛점을

두었던 두번째 수준의 디지털 디바이드의 출현차원으로서 역량을 강조한 것이다. 